\title{
THE ROLE OF LEADERSHIP IN INSTILLING ORGANIZATION CITIZENSHIP BEHAVIOR
}

\author{
Maria FRANGIEH ${ }^{a}$, Doina POPESCU ${ }^{b}$ \\ ${ }^{a, b}$ Bucharest University of Economic Studies, Romania
}

DOI: $10.24818 / \mathrm{IMC} / 2020 / 03.05$

\begin{abstract}
This article examines the effect of Transformational Leadership Style on employees' Organization Citizenship Behavior. The latter is being focused upon as a determinant factor in "individual and group performance", which, in turn, leads to an effective "organization performance". The ability to motivate employees to accomplish outside the terms and conditions of their signed work contract is one of many effective leadership's missions (Bass, 1997). Based on abundant literature, transformational leadership had proven to be effective in managing organizations. Hence, the purpose of this research is to answer the following question: does transformational leadership style affect the development of organizational citizenship behavior? The main objective is to demonstrate how transformational managers implant organization citizenship behavior among their subordinates. The study was conducted in a private hospital in the north of Lebanon on a sample of thirty nurses in both the surgery and the urgent care departments. Choosing the hospital industry, and specifically those two departments, seemed logic in the light of covid-19 pandemic (which caused an increase in the number of admitted patients) and severe economic crisis (which pushed many hospitals to impose salaries' late payments and cutoffs). I believe that the effect of the managers' transformational style could be easily depicted in the light of more workload and less rewards. The research findings indicated that transformational leaders considerably impact employees' organizational citizenship behavior. This fact reveals the necessity of training managers to exhibit their transformational style which will obviously lead to the wellbeing of all stakeholders.
\end{abstract}

KEYWORDS Organization Citizenship Behavior, Organizational Performance, Transformational Leadership

\section{INTRODUCTION}

Lebanon is facing the worst socio - economic crisis since 1920, having to manage also the Covid-19 pandemic that had exploded during the country's official breakdown. Both bad economic conditions and lockdown forced Lebanon into a quasi-complete closure since October 2019. A large number of organizations were forced to permanently discontinue their activities or to downsize them. This highlighted the concept of organization success. An organization's success depends on its performance in effectively exploiting its resources. Consequently, it is essential to look at organizations own resources that might help them into rising like a phoenix from ashes. Barney (1991) categorized those resources into:

- Physical capital resources, such as property, plant, equipment, technology

- Organizational capital resources that is the formal organization structure

- Human capital resources such as employees’ knowledge, experience, and training

\footnotetext{
${ }^{*}$ Corresponding author. E-mail address: frangieh.m@gmail.com
} 
As pointed out by Armstrong and Taylor (2014), human capital resources, personalized in employees and materialized though their good performance, are assets. Since employees are directly involved in this success formula, "organizational behavior" is a key player in the performance game (Popescu et al., 2019; Duțu et al., 2015). This field helps in identifying two primary outcomes that highly contribute into achieving an overall organizational performance: Employees Performance and Commitment.

This research focuses on a key element of employees' performance, the Organization Citizenship Behavior (Rotundo \& Sackett, 2002; Ceptureanu et al., 2017). It is a multidimensional perception which covers several sides of employees' voluntary extra work behavior not required as per their job description (Humphrey, 2012; López et al., 2013). Its importance stems from the fact that it contributes to organizations' effectiveness (Podsakoff et al., 2009) through resources' utilization, origination, and flexibility (Gholam H., 2009), adding to that quickness, competence, and customer satisfaction (Johnson et al., 2002).

Effective managers guide employees toward good task performance and organization commitment. When this happens, organization's performance would increase, and, subsequently, increase its chance of survival. In the workplace context, effective leadership is defined as the capacity to influence the performance of employees which leads to overall positive consequences (Gibson et al., 1991). There is a significant indication that transformational leadership style is effective (Avolio \& Bass, 2002). It raises subordinates' commitment and performance levels, both of which are positive outcomes when it comes to organization performance (Burns, 1998; Somers \& Birnbaum, 1998; Tichy \& Devanna, 1986). A strong effect of transformational leadership on organizational citizenship behavior's elements had been reported in many researches (Chiaburu et al., 2013; Judge \& Piccolo, 2004).

Hence, this research observes the effect of transformational leadership styles on organizational performance through pushing employees to enthusiastically and voluntarily perform extra work. To sum up with, this research aims to answer the following question: does transformational leadership style affect the development of organizational citizenship behavior? Based on literature, the answer to this question will be anticipated in the form of the following hypothesis: transformational leadership style stimulates employees to do extra work for the benefit of the firm.

The research starts with a quick literature review regarding the concept of organization performance, the concept of organization citizenship behavior, and transformational leadership. It then follows a quantitative approach adopting a survey where questionnaires were sent to thirty nurses in a private hospital in the north of Lebanon in both the surgery and the urgent care departments. Due to covid-19 pandemic (which caused an increase in the number of admitted patients) and severe economic crisis (which pushed many hospitals to impose salaries' late payments and cutoffs), the sample chosen in this industry was thought to be logic. The managers' transformational style effect could be certainly represented in the light of extra amount of work and less rewards in the two mentioned departments. Data were regressed using SPSS and analyzed using statistical regression model. The research results clap hands to literature review by showing that transformational leaders noticeably influence employees' organizational citizenship behavior. They echoed Park \& Rainey (2008) allusion that the reward for communal employees is primarily the satisfaction derived from performing well for the public good itself, an outcome of the transformational managers' inspirational motivation. Therefore, transformational managers 


\section{2- LITERATURE REVIEW}

\section{1- Organization Performance}

Organizations are a controlled gathering of employees having common purposes to attain. Performance relates to how competently they perform their tasks to reach those objectives. Hence, performance is closely related to goals achievement: reaching goals means that the company is effectively performing (Colquitt et al, 2009). The concept of performance by itself is a built-in confusion: Its nature oscillates between a result, a behavior, or a competence.

- Performance as a result: the accomplishment of jobs related to overall strategic goals, entailing both customers and investors satisfaction (Kane, 1996)

- Performance as a personal behavior: It is a series of individual activities connected to organizations' goals (Campbell, 1990). Only behaviors linked to objectives may be labeled as performance. Supporters of this perspective rely on the organization citizenship behavior, which push employees to perform the best they can, regardless of the formally stated job descriptions and payrolls. By exhibiting this behavior, they are showing protection toward their firms; they are more committed, and aid their colleagues when needed (Batemen \& Organ, 1983)

- Performance as a competence: Based on this scope, individuals are being assessed as per each one's proficiency. The greater their proficiency levels, the greater their performance, and the closer the organization is to success (Carroll \& Mccrakin, 1998)

An effective organizational performance had been associated with employee productivity, firm productivity, and even firm survival (Huselid, 1995; Welbourne \& Andrews, 1996). The organizational behavior field identifies two primary outcomes that highly contribute into achieving an overall organizational performance: Individual and Team Job Performance and Organizational Commitment (Colquitt et al, 2009). Therefore, understanding the relationship between job performance and commitment with the performance as a whole helps to achieve success and to guarantee survival in the long run. Job performance possesses three dimensions (Campbell, 1990):

- Task Performance which refers to how employees behave while transforming inputs into outputs. This performance is classified as either routine (involving known responses to normal demands) or adaptive (involving innovative responses to unusual demands) (LePine et al., 2000)

- Counterproductive Behavior which refers to employees' intentional behaviors to hamper goals' realization. It may be property damage (sabotage, robbery), production impairment (resources waste), political nonconformity (gossip), and personal violence (harassment and manipulation).

- Citizenship Behavior which refers to employees' activities, rewarded or not, that improve the overall quality of the workplace. It is reflected in helping and respecting others, and improving and supporting the organization

Not ignoring the importance of task performance and Counterproductive behavior, this research focuses on the third element in increasing job performance, which is organizational citizenship behavior.

\section{2- Organization Citizenship Behavior}

Performance is a major issue in any company (Peng, 2004). Katz (1964) and Organ (1988) highlighted the rapport between collective organization citizenship behavior and organizational performance. This behavior is a mean that promotes performance (Motowidlo, 2000) and the effective functioning of the organization (Organ 1988). It helps managers into specifying the identity of the best subordinates and to work hard to retain them, avoiding high employees turnover 
rate (Niehoff, 2005). In addition, its presence secures a stable performance and provides the firm the capacity to become accustomed to changes (Podsakoff \& MacKenzie, 1997). It has a positive

relationship with clients' observation of the firm's service quality which ultimately stimulates the firm’s performance (Bienstock et al., 2003; Kelley \& Hoffman, 1997).

Organization citizenship behavior is the extra work employees perform, a set of natural tasks not required by their job description contract but important for companies to achieve goals (Katz, 1964). It is defined as: “...individual behavior that is discretionary, not directly or explicitly recognized by the formal reward system and that in the aggregate promotes the effective functioning of the organization" (Organ, 1988). As made clear in the definition above this behavior captures three major points. It starts with term "discretionary" which entails its optional trait. It is a matter of personal choice, not enforced by the terms and obligations of the work contact nor the job requirement. In other terms, the company cannot hold the employee accountable in case he/she does not display such a behavior. Second, the definition stresses on the fact that this behavior is for free. Employees do not have to expect a raise in salary or in position after exhibiting such a behavior. Last, despite the fact that it is optional and not rewarded, this behavior, when accumulated, leads the organization toward effective performance.

The capacity of a firm to stimulate employees to behave above and beyond the call of duty would certainly increase its competitive advantages and obviously survival in the long run (Barney, 1991). This fact raises again the importance of the human capital and recognize it as a major firm's asset. According to Organ (1988), this behavior is explained through five scopes: altruism, conscientiousness, sportsmanship, courtesy, and civic virtue. Altruism signifies assisting stakeholders (colleagues, and firms' customers and suppliers) with a job or problem. It targets a specific person under the benevolent mission of helping him/her while facing the problem. Conscientiousness talks about accomplishing beyond the minimum required behavior, such as regular attendance, cleanliness, punctuality, and use of break time. Sportsmanship refers to the employees' ability not to spend time nor energy paying complaining about minor matters, which obviously occur within companies enclosing, and focusing on what is wrong. This characteristic is important because it does not force managers to dedicate time listening to small complaints that lead to nothing, and to focus rather on important tasks. Courtesy anticipates the occurrence of a problem by reminding colleagues ahead of time of deadlines, and passing them important information. Civic virtue highlights the employees' involvement in the organization policies such as reading emails, going to non-mandatory but important. The questionnaire used in this relies on these dimensions mentioned by Organ (1988).

To sum up with, this behavior helps the company a lot in reaching its objectives and guaranties its survival. The question now is the following: how do managers stimulate employees to exhibit this kind of behavior?

\section{3- Transformational Leadership}

An organization is an economic and social structure that brings together materials, financial, and human resources to produce what attracts and satisfies consumers. High competition, labor turnover, and corruption are obstacles that might prohibit management from realizing high financial performance, essential for survival. To be able to flexibly overcome obstacles and to cope with changes, organizations need top quality effective leaders (Harris, 2007). Leadership plays an important role in nurturing and augmenting employees' behavior (Khalili, 2016). It is an art that

describes the rapport between a person and followers, where the former influences the latter to execute actions while properly monitoring and guiding them (Bass, 1990). The more effective 
leaders are, the greater the subordinates' organization commitment and task performance, the greater the organization performance (Colquitt et al., 2009).

It should be noted that effective leaders' styles are being increasingly considered as transactional and/or transformational (Avolio \& Bass, 2002). In this research, the focus is on the transformational leaders, who, in addition to managing operations, they create change strategies that transport the organizational unit to higher levels of performance. They motivate employees by

\section{3- METHODOLOGY AND RESULTS}

\section{1 - Methodology}

The research adopted a quantitative approach based on a survey where questionnaires were sent to thirty nurses in a private hospital in the north of Lebanon in both the surgery and the urgent care departments. To enable this research, two types of data had been utilized:

- Secondary data - Literature Review: Data was accessed via books, articles, journals, and internet websites.

- Primary data - A questionnaire which enclosed two major parts: transformational leadership and organization citizenship behavior. It was sent via emails to the respondents who were asked to answer several statements according on a 5-point Likert type scale ranging from $1=$ strongly disagree to 5 = strongly agree.

Transformational Leadership was measured based on the Multi-Factor Leadership Questionnaire (MLQ) developed by Bass (1985). It comprises three scales; transformational leadership, transactional leadership, laissez faire leadership. Since transformational leadership is the focus of this research, it was used alone. Only three measures were used to identify which are charisma, inspirational motivation and intellectual stimulation. They constitute the independent variables. Each variable was described through a series of routine behavior performed by the manager.

\section{Charisma}

- My manager is always seeking new opportunities for the organization

- My manager paints an interesting picture of the future for us

- My manager has a clear understanding of where we are going

- My manager inspires others with his/her plans for the future

- My manager is able to get others committed to his/her dream of the future

Inspirational Motivation

- My manager leads by doing rather than just telling

- My manager provides a good model to follow

- My manager leads by example

Intellectual Stimulation

- My manager has provided me with new ways of looking at things which used to be a puzzle for me

- My manager has ideas that have forced me to rethink some of my own ideas I have never questioned before

- My manager has stimulated me to rethink about problems in new ways 
Organization Citizenship Behavior was measured according Organ's (1988) five dimensional classification which constitute the dependent variables. Each variable was described through a series of routine behavior performed by the employee.

Courtesy

- I Consider the impact of his/her actions on workers

- I try to avoid creating problems for co workers

- I answer the request of information as soon as possible

- I Communicate with coworkers before taking actions that influence others

- I Take steps to try to prevent problems with other co workers

- I Respect the right of other coworkers to use public facilities

Altruism

- I Help orient new people even though it is not required

- I am always ready to lend a helping hand to those around him/her

- I am willing to spend time to help others to solve work related problems

- I help others who have heavy work loads

- I help others who have been absent

Conscientiousness

- I am conscientious

- I believe in giving an honest days' work for an honest day’s pay

- I do not take extra breaks

- I work on a job project until it is completed even if it means coming earlier or staying later than normal

Sportsmanship

- I do not consume a lot of time complaining about trivial matters

- I do not find faults with what the organization is doing

- I am not the classic squeaky wheel that always need greasing?

- I do not tend to make mountains out of molehills

- I always focus on what's right instead of what is wrong

Civic virtues

- I always tend to be updated regarding the changes in the company

- I enthusiastically attend non-mandatory training sessions

- I actively participate in the meetings

- I provide constructive suggestions for company changes. 
Results of this study were evaluated using the Statistical Package for the Social Sciences (SPSS). Descriptive statistics was used to present the main characteristics of the sample. Hypothesis was tested using Person Correlation Coefficient.

\section{2- Results}

Findings showed a positive correlation between the transformational aspects of leadership and organizational citizenship behavior dimensions. All the organizational citizenship aspects were proved to increase as managers adopt a transformational style of leadership. The hypothesis predicted that there is a positive significant relationship between transformational leader's style of managers and the nurses' organization citizenship behavior OCB ( 0.01 level of significance). Those results came with no surprise, as many other researches led to the same results (Jha, 2014; Purvanova et al., 2006; Wang et al., 2011). This conclusion implies that when managers act as transformational leaders, subordinates will become more betrothed in citizenship behavior. In this case, employees will be eager to perform more than what is required from them as per contract, assist stakeholders in times of trouble, and secure a positive atmosphere at workplace (BabcockRoberson \& Strickland, 2010). Due to the ability of transformational managers to motivate subordinates to perform outside the employment contract box (Bass \& Avolio, 1994), they can push them to continuously show more of the citizenship behavior (Podsakoff et al., 1990). As a matter of fact, transformational managers are able to change the way their employees think about their jobs. They can make them feel that their job by itself is meaningful and rewarding. By doing so, they naturally involve them in citizenship performance (Boerner et al., 2008). By encouraging their subordinates to abide by the organization's mission, transformational managers create shared goals and stimulate everyone to realize them whatever it takes from them as extra work (Guay \& Choi, 2015).

\section{CONCLUSIONS}

The objective of this article was to examine the relationship between transformational leadership and organization citizenship behavior. The hypotheses was reinforced by data. The research findings indicated the expected positive and important rapport between transformational leaders and nurses' organization citizenship behavior. This result is constant with previous empirical researches. Abundant studies demonstrated the existence of a link between transformational leadership style and individual, group, and firm performances (Barling et al., 1996; Hater \& Bass, 1988; Jung \& Sosik, 2002; Ramey, 2002; Stumpf, 2003; Zhu et al., 2005).

Their style can best be defined by its effects on their subordinates. Effects such as trust, admiration, loyalty, and respect toward leaders are noted. Transformational leaders empower and motivate others to achieve more than what they were expected to do (Boerner, 2007; Strang, 2005). They enhance subordinates' performance, quantitatively and qualitatively, by stimulating their organizational citizenship behavior. This behavior, as previously described, has an important effect on organizational effectiveness and efficiency (Boerner, 2007). Consequently, transformational leadership stimulate subordinates to willingly perform extra effort, to reduce absenteeism and employee turnover rates, which increase productivity (Bass \& Avolio, 1994). Therefore, performance and commitment levels would increase (Podsakoff et al., 1996). This research draws the attention on the importance of transformational leadership style of managers in engaging nurses in citizenship behaviors in Lebanese hospitals. This suggests that management at hospitals, like in any other organization, should consider excessive and continuous training sessions to shape managers' skills into the transformational frame. 
Through their charisma, inspiration, consideration, and stimulation. transformational leaders increase their subordinates' trust and commitment which lead to performances that exceeds normal expectations. Besides managing operations, transformational leaders also construct change strategies that also lead organizations to higher levels of performance (Kieu, 2010).

Many challenges were encountered while preparing this research, mainly due to the nature of the nursing carrier and the size of the sample.

First, nurses are normally exhausted during and after their shift. This fact might had affected the way they had answered the questionnaire. Perhaps, due to extreme tiredness, they wanted to finish the questionnaire quickly, and therefore they picked the first answer that came to their mind, without giving it a second thought.

Second, as nurses, their personality is characterized by their caring nature. They are used to provide assistance since day one in their carrier. It is in the nature of their work. This might pose some questions regarding their citizenship behavior. Is really influenced by a manager or by the nature of their profession?

Third, the sample size was intended to be larger than thirty, however, only this number answered by replying to the email sent during the first week of October 2020. This is not surprising since they had their own demons to fight: more workload with less pay during a pandemic.

Consequently, one cannot generalize the hypotheses in Lebanese private hospitals, despite the fact that it had been proved by numerous researches, as seen progressively in this research.

\section{REFERENCES}

Armstrong, M. \& Taylor, S. (2014). Armstrong's handbook of Human resource management Pratice (13rd edition). London, UK: Kogan Page Limited.

Avolio, B. \& Bass, B. (2002). Developing Potential Across a Full Range of Leadership Styles: Cases on Transactional and Transformational Leadership. Mahwah, NJ: Lawrence Erlbaum Associates.

Babcock-Roberson, M. E. \& Strickland, O. J. (2010). The relationship between charismatic leadership, work engagement, and organizational citizenship behaviors. Journal of Psychology, 144(3), 313-326.

Barling, J., Weber, T. \& Kelloway, E. (1996). Effects of Transformational Leadership Training on Attitudinal and Financial Outcomes: A Field Experiment. Journal of Applied Psychology, 81, 827-832.

Barney, J. (1991). Firm Resources and Sustained Competitive Advantage. Journal of Management, 17(1), 99-120.

Bass, B. (1985). Leadership: Good, Better, Best. Organizational Dynamics, 13, 26-40.

Bass, B. (1990). Handbook of Leadership: Theory, Research, and Managerial Applications. New York, NY: Free Press.

Bass, B. M. (1997). Does the transactional-transformational leadership paradigm transcend organizational and national boundaries? American Psychologist, 52, 130-139.

Bass, B. \& Avolio, B. (1994). Improving Organizational Effectiveness Through Transformational Leadership. Thousands Oak, CA: Sage.

Batemen, T. \& Organ, D. (1983). Job Satisfaction and the Good Soldier: The Relationship between Affect and employee Citizenship. Academy of Management Journal, 26, 587-595.

Bienstock, C. C., DeMburnoranville, C. W. \& Smith, R. K. (2003). Organizational citizenship behavior and service quality. Journal of Services Marketing, 17(4/5), 357-378.

Boerner, S. (2007). Follower Behavior and Organizational Performance: The Impact of transformational Leadership. Journal of Leadership and Organizational Studies, 13, 15-26. 
Boerner, S., Dutschke, E. \& Wied, S. (2008). Charismatic leadership and organizational citizenship behaviour: examining the role of stressors and strain. Human Resource Development International, 11(5), 507-521.

Burns, J. (1998). Transactional and transforming leadership. In G. Hickman (Ed.), Leading organizations: Perspectives for a new era. Thousand Oaks, CA: Sage Publications.

Campbell, J. (1990). Modeling the Performance Prediction Problem in Industrial and Organizational Psychology. In M. Dunnette (Ed.), Handbook of Industrial and Organizational Psychology (pp. 687-732). Palo Alto, CA: Consulting Psychologists Press Inc.

Carroll, A. \& Mccrakin, J. (1998). The Competent Use of Competency-Based Startegies for Selection and Development. Performance Improvement Quarterly, 2(3), 45-63.

Ceptureanu, E. G., Ceptureanu, S. I. \& Popescu, D. I. (2017). Relationship between Entropy, Corporate Entrepreneurship and Organizational Capabilities in Romanian Medium Sized Enterprises. Entropy, 19(8).

Chiaburu, D. S., Lorinkova, N. M. \& Van Dyne, L. (2013). Employee's social context and changeoriented citizenship: A meta-analysis of leader, coworker, and organizational influences. Group \& Organization Management, 38, 291-333.

Colquitt, J., LePine, J. \& Wesson, M. (2009). Organizational Behavior: Improving Performance and Commitment in the Workplace. New York, NY: McGraw-Hill.

Duțu, C., Luchian, A., Starcu, E. \& Savulescu, F. (2015). Surgical team and surgical communication. Romanian Journal of Military Medicine, 118(3).

Gholam Hosseini, A. (2009). Affective factors, components and consequences of organizational citizenship behavior. Journal of Human Development Police, 7(31).

Gibson, J. L., Ivancevich, J. M. \& Donnelly, J. H. Jr. (1991). Organizations: Behavior, Structure, Processes. Irwin, IL: Homewood.

Guay, R. P. \& Choi, D. (2015). To whom does transformational leadership matter more? An examination of neurotic and introverted followers and their organizational citizenship behavior. The Leadership Quarterly, 26(5), 851-862.

Harris, A. e. (2007). Distributed leadership and organizational change: Reviewing the evidence. Journal of Education Change, 8(4), 337-347.

Hater, J. \& Bass, B. (1988). Superiors' Evaluations and Subordinates' Perceptions of Transformational and Transactional Leadership. Journal of Applied Psychology, 73(4), 695702.

Humphrey, A. (2012). Transformational leadership and organizational citizenship behaviors: the role of organizational identification. The Psychologist-Manager Journal, 15(4), 247-268.

Huselid, M. (1995). The impact of human Resource Management Practice on Turnover, Productivity, and Corporate Financial Performance. Academy of Management Journal, 38, 635672.

Jha, S. (2014). Transformational leadership and psychological empowerment: Determinants of organizational citizenship behavior. South Asian Journal of Global Business Research, 3(1), 18-35.

Johnson, D. E., Kiker, D. S., Erez, A. \& Motowidlo, S. J. (2002). Liking and Attributions of Motives as Mediators of the Relationships Between Individuals' Reputations, Helpful Behaviors, and Raters' Reward Decisions. Journal of Applied Psychology, 87(4), 808- 815.

Judge, T. A. \& Piccolo, R. F. (2004). Transformational and transactional leadership: A metaanalytic test of their relative validity. Journal of Applied Psychology, 89, 755-768.

Jung, D. \& Sosik, J. (2002). Transformational Leaderhip in work Groups: The role of Empowerment, Cohesiveness, and Collective Efficacy on Perceived group Performance. SAGE Journals, 33(3).

Kane, J. (1996). The Conceptualization and Representaion of Total Performance Effectiveness. Human Resource Management Review, 123-145. 
Katz, D. (1964). The motivational basis of organizational behavior. Behavioral Science, 9, 131-146.

Kelley, S. W. \& Hoffman, K. D. (1997). An investigation of positive affect, prosocial behaviors and service quality. Journal of Retailing, 73(3), 407-427.

Khalili, A. (2016). Linking transformational leadership, creativity, innovation, and innovation supportive climate. Management Decision, 54(9), 2277-2293.

LePine, J., Colquitt, J. \& Erez, A. (2000). Adaptability for Changing Task Contexts: Effects of General Cognitive Ability, Consciousness, and Openness to Experience. Personnel Psychology, 53, 563-593.

López-Domínguez, M., Enache, M., Sallan, J. M. \& Simo, P. (2013). Transformational leadership as an antecedent of change-oriented organizational citizenship behavior. Journal of Business Research, 66(10), 2147-2152.

Motowidlo, S. J. (2000). Some basic issues related to contextual performance and organizational citizenship behavior in human resource management. Human Resource Management Review, 10(1), 115-126.

Niehoff, B. P. (2005). A theoretical model of the influence of organizational citizenship behaviors on organizational effectiveness. In D. L. Turnipseed (Ed.), Handbook of organizational citizenship behavior (pp.385-397). New York, NY: Nova Science Publishers.

Organ, D. W. (1988). Organizational citizenship behavior: The good soldier syndrome. Lexington, MA: Lexington Books.

Park, S. M. \& Rainey, H. G. (2008). Leadership and public service motivation in U.S. Federal Agencies. International Public Management Journal, 11, 109-142.

Peng, M. W. (2004). Identifying the big question in international business research. Journal of International Business Studies, 35(2), 99-108.

Podsakoff, N. P., Whiting, S. W., Podsakoff, P. M. \& Blume, B. D. (2009). Individual-and organizationallevel consequences of organizational citizenship behaviors: a meta-analysis. Journal of Applied Psychology, 94(1), 122-141.

Podsakoff, P. M. \& MacKenzie, S. B. (1997). An examination of substitutes for leadership within a levels-of-analysis framework. Leadership Quarterly, 6(3), 289-328.

Podsakoff, P. M., MacKenzie, S. B. \& Bommer, W. H. (1996). Transformational leader behaviors and substitutes for leadership as determinants of employee satisfaction, commitment, trust, and organizational citizenship behaviors. Journal of Management, 22, 259-298.

Podsakoff, P. M., MacKenzie, S. B., Moorman, R. H. \& Fetter, R. (1990). Transformational leader behaviors and their effects on followers' trust in leader, satisfaction, and organizational citizenship behaviors. The Leadership Quarterly, 1(2), 107-142.

Popescu, AL., Costache, R. S., Săvulescu, F., Jinga, M., Ioniță-Radu, F. (2019). Internal Medicine Papers. Romanian Journal of Military Medicine, 122.

Purvanova, R. K., Bono, J. E. \& Dzieweczynski, J. (2006). Transformational leadership, job characteristics, and organizational citizenship performance. Human Performance, 19(1), 1-22.

Ramey, J. (2002). The Relationship Between Leadership Styles of Nurse Managers and Staff Nurse Job Satisfaction in Hospital Settings (Marshall University College of Nursing and Health Professions, Huntington, 2002). Retrieved from https://mds.marshall.edu/cgi/viewcontent.cgi?referer=https://www.google.com/\&httpsredir=1\& article $=1132 \&$ context $=$ etd

Rotundo, M. \& Sackett, P. (2002). The Relative Importance of Task, Citizenship, and Counterproductive Performance to Global Ratings of Job Performance: A Policy Capturing Approach. Journal of Applied Psychology, 87(1), 66-80.

Somers, M. \& Birnbaum, D. (1998). Work-related Commitment and Job Performance: It's also the Nature of the Performance that Counts. Journal of Organzational Behavior, 19(6), 621-634.

Strang, K. (2005). Examining Effective and Ineffective Transformational Project Leadership. Team Performance Management, 11(3/4). 
Stumpf, M. (2003). The Relationship of Perceived Leadership Styles of North Carolina County extension (North Caroline State University, Raleight, 2003). Retrieved from https://repository.lib.ncsu.edu/bitstream/handle/1840.16/5913/etd.pdf?sequence=1\&isAllowed= $\mathrm{y}$

Tichy, N. \& Devanna, M. (1986). Transformational leadership. New York, NY: Wiley.

Wang, G., Oh, I.-S., Courtright, S. H. \& Colbert, A. E. (2011). Transformational leadership and performance across criteria and levels: a meta-analytic review of 25 years of research. Group and Organization Management, 36(2), 223-270.

Welbourne, T. \& Andrews, A. (1996). Predicting the Performance of Initial Public Offerings: Should Human Resources Management be in the Equation?. Academy of Management Journal, 39, 891-919.

Zhu, W., Chew, K. \& Spangler, W. (2005). CEO Transformational Leadership and Organizational Outcomes: The Mediating Role of Human Capital Enhancing Human Resource Management. The Leadership Quarterly, 19, 39-52. 